\section{BA Institute of \\ YK Business Administration \\ 六下 \\ Karachi \\ Leadership and Ideas for Tomorrow}

Business Review

Volume 10 Issue 2 July-December 2015

7-1-2015

\title{
Supply chain performance measurement for services: An operational level framework
}

\author{
Asher Ramish \\ University of Management and Technology, Lahore, Pakistan \\ Sarwar M. Asher \\ University of Management and Technology, Lahore, Pakistan
}

Follow this and additional works at: https://ir.iba.edu.pk/businessreview

Part of the Operations and Supply Chain Management Commons

\section{c) (i)}

This work is licensed under a Creative Commons Attribution 4.0 International License.

\section{Recommended Citation}

Ramish, A., \& Asher, S. M. (2015). Supply chain performance measurement for services: An operational level framework. Business Review, 10(2), 130-147. Retrieved from https://doi.org/10.54784/ 1990-6587.1358

This article is brought to you by iRepository for open access under the Creative Commons Attribution 4.0 License and is available at https://ir.iba.edu.pk/businessreview/vol10/iss2/9. For more information, please contact irepository@iba.edu.pk. 


\title{
CASE STUDY
}

\section{SUPPLY CHAIN PERFORMANCE MEASUREMENT FOR SERVICES:}

\section{An Operational levelFramework}

\author{
Asher Ramish \\ University of Management and Technology, Lahore, Pakistan \\ Sarwar M. Azhar \\ University of Management and Technology, Lahore, Pakistan
}

\begin{abstract}
:
\end{abstract}
Purpose

The purpose of the study is to propose a consolidated and comprehensive operational level framework of performance metrics to facilitate the supply chain integration in the service industry.

Design/methodology/approach

In order to do so, we rely on a systematic review procedure to delineate and thus integrate the measures into factors. This paper draws upon prior work done on performance measure in supply chain integration.

\section{Findings}

These measures will then be assigned by incorporating industrial practice to various factors that we believe are relevant to the measure of performance in the integrated supply chain system in the service industry.

\section{Research limitations/implications}

The manuscript is a conceptual paper so there is a need to test the generalizability of the framework in the broader service industry by conducting empirical study.

\section{Practical implications}

This analysis will enable the identification of the problems that surround outcome assessment within and across single supply chains and extend existing knowledge in the end-to-end supply chain performance measurement in the service industry. Further this analysis should provide some vital insights as to how service organizations can improve their performance evaluation systems to become more effective in supply chains.

\section{Originality/value}

This study aims to not only identify the gaps present in the service supply chain performance measurement at the operational level but tries to fill the knowledge gap to suggest operational level performance metrics in facilitating the supply chain integration in the service industry.

Keywords: Supply chain, Performance measurement, Services supply chain, Service supply chain, Conceptual framework, SCOR Model, Scorecard, KPI, Performance Measurement Methods, Performance metrics 


\section{Introduction}

Supply chain integration has been a topical issue since the late 1980s (Stevens, 1989). It aims to integrate the supply chain partners through strategic collaboration of managing the intra and inter-organisation processes (Flynn et al, 2010). Since then, there have been research studies that have approached the subject from various aspects and to name a few, these are process integration (e.g., Serve et al., 2002; Wang et al, 2010), integration types (e.g., Frohlich and Westbrook, 2001)- vertical, horizontal, network and hierarchical integrations, information systems (e.g., Serve et al., 2002), as well as performance impacts (e.g., Flynn et al, 2010). However, there is a lack of models to assess the effectiveness of integrated supply chain, thus weakening the efficacy of integration. To this end SCOR model offers a few indicators that can help in this regard. Kaplan and Norton (1992) on the other hand have also proposed a well known tool, the Balanced Scorecard, in order to measure the performances of the supply chains involvingnot only the financial side of the supply chains but also suggesting KPIs to streamline the internal business process, the customer, learning and growth. The KPIs suggested in Balanced Scorecard help maintain an equilibrium between short term and long term objectives, financial and non-financial measures, lagging and leading indicators and between in-plant and out of plant performance outlook (Kaplan and Norton, 1992, 1993, 1996).

Other recent studies focusing on the issues of performance measurement and have attempted to provide theoretical frameworks to measure the integrated supply chain performances (e.g., Abu Bakar, Hakim, Chong, \& Lin, 2010; Dey, Hariharan, \& Clegg, 2006; Wang, Lai, \& Zhao, 2008; Hofmann \& Locker, 2009; Forslund \& Jonsson, 2007). A few authors have made an effort to study performance in the light of service innovation, namely, (Wang et. al., 2015) also. However, majority of the research in this genre in general lack a holistic approach that could address the fundamendal issue of integration of various components within a representative and generalizable performance model. Moreover, we note that most of the researches generally focus on the manufacturing sector with limited insights provided to the service sector supply chain management. These limits our insights for performance measurement in services supply chains and points to a major gap in our knowledge, in effectively managing the service supply chain system, and this apparent gap forms the basis of the presentresearch work.

It seems that the reason for this lack of focus comes from the difficulty to identify the suppliers of the intangibles compared to the manufacturing industries. Literature emphasises the difference in product and service marketing focusing on the distinguishing characteristics of services. This distinctive characteristics of services has also been proposed in the context of managing supply chain by Fitzsimmons and Fitzsimmons (1998), who opine that services are strikingly dissimilar from manufacturing, with different managerial implications. This indicates that the empirical findings for manufacturing or product oriented supply chains should not be generlized to services supply chains, service is intangible in nature and it becomes difficult to account for the outcomes. Service outcomes usually tend to be heterogeneous because of heterogenity of inputs. Moreover customer interaction in the operation of the service industry supply chain plays a critical role in performance evaluation that makes it difficult to measure.

The purpose of the study, therefore, is to propose a consolidted and comprehensive framework of performance metrics at operational levelto facilitate the supply chain integration in the service industry.

The way this is being approached is by asking ourselves "how can we measure and control supply chain performance in the service sector" and secondly "are there metrices / performance measures that are relevant to the industry". 
In order to do so, we rely on a systematic review procedure to delineate and thus integrate the measures into factors. This paper draws upon prior work done on performance measure in supply chain integration. These measures will then be assigned by incorporating expert opinion to various factors that we believe are relevant to the measure of performance in the integrated supply chain system in the service industry.

Before explaining the prior work selection procedure and our analysis, we would like to briefly discuss models which have gained currency in the broader field of supply chain performance measure and attempt to demonstrate the gaps therein with relation to their application to the service supply chains.

\section{Supply chain performance models: A literature review}

Prior to discussing what is said by the authors with regard to the supply chain performance measurement in service industries, it is important to first reflect on supply chain itself and its implications in service industry. A supply chain in general comprises of all business entities involved, directly or indirectly, in satisfying a customer's request. The supply chain not only includes the manufacturer and suppliers, but also transporters, contractors, warehouses, manufacturing plants, vendor plants, retailers, and customers themselves and thus indicates a network of systems and processes. On the other hand, supply chain management in the recent years has been defined as:

"The management of a network of relationships within a firm and between interdependent organizations and business units consisting of material suppliers, purchasing, production facilities, logistics, marketing, and related systems that facilitate the forward and reverse flow of materials, services, finances and information from the original producer to final customer with the benefits of adding value, maximizing profitability through efficiencies, and achieving customer satisfaction."(Stock and Boyer, 2009, page, 707)

Managing supply chains involve coordination of all business activities making the supply chain end product more networked.Concept of supply chain is applicable in both manufacturing and services organizations as the prime focus revolves around integration of the end-to-end organization i.e. involving suppliers, suppliers of the suppliers, customers and customers of the customers, thereby allowing supply chain principles to be applied in the services context too.

Nevertheless a distinction between manufacturing and services has to be made to enable us to set the stage for discussing the supply chain within the service industry and we rely on Sampson (2000) description of services.

Services are intangible products that may or may not be difficult to store, they are also produced and consumed concurrently at the time when demand arises and not before. This is a necessity in most of the cases and not a choice. Further, if at the time of customer demand, the service provider is not able to produce the service then he / she might lose the order. Unlike tangible products, most services are frequently available for offering and would not be depleted on getting sold. Moreover, to meticulously identifying and evaluating the contribution of all the relevant suppliers in the upstream is theoretically and practically difficult given the involvement of customers at that end. This fact is highlighted by Sampson (2000), while introducing the bi-directional supply chains. In that he highlights the duality of producing and consuming services which is specific to service oriented businesses. Services are, on the whole, labor intensive actions and highly dependent on managing the employees and knowledge efficiently. In line with this proposition, it is important to note that customers do not only sit downstream of the service supply chain but also manage many of the inputs in upstream part of the supply chain. Sampson (2012) also has explained the translation from inventory to capacity as far as service industries are concerned. Sampson and Spring (2012) has tried to relate the design and development process in the manufacturing supply chains 
with the ones in the service supply chains. In addition to this, service customers according to Sampson and Spring (2012) are component suppliers of their minds, bodies, belongings and information. Therefore, information also acts as a raw material of service supply chains. There are a few other authors who have tried to analyze the effect of introduction of services into traditional manufacturing firms, namely, (Bustinza et. al., 2013 and Darkow et. al., 2015), while (Chahal and Kaur, 2014) took banking sector for their studies in organizational performance. A service dominant logic approach was used to study supply chain performance by (Maas et. al., 2014). One unique study conducted by Wang et. al. (2013) stressed on the comparison of various key performance indicators for sustainability of the earth performance, which also gives an overview of how one can measure the services supply chains and what else can be the indicators to focus on in the future.

With regard to the service performance aspect of the supply chain outcomes in service industry, we find very few researches i.e. (Seth, Deshmukh, \& Vrat, 2006; Gomes, Yasin, \& Lisboa, 2004), which is perhaps an indicator of the difficulty in assessing the outcomes at various levels of deliverables in the service oriented organization.Many writers however, have proposed various tools in this regard, for example, a performance management system has been developed for medical service authority (De Toni, Fornasier, Montagner, \& Nonino, 2007), but the system could not be applied in a more generalized manner.Nevertheless a shortage of studies in this area indicates a gap in the knowledge where supply chain integration for service industry and its performance measures are concerned.

In the next section the paper will present a few models for supply chain performance measures that are more popular in their relevance to application in service industry, however they do lack in comprehensiveness.

\section{Fitzgerald service performance dimensions}

Fitzgerald et al. (1991) suggest six service performance dimensions, that make services different from manufacturing and these dimensions include the following:

1- $\quad$ Competitiveness (with a focus on customer)

a. Ability to win new customers.

b. Customer loyalty.

2- $\quad$ Financial performance (with a focus on asset management)

a. Asset turnover

b. Control of labour and capital costs

c. Profit per serve

3- $\quad$ Flexibility (with a focus on functional strategy)

a. Building volume, delivery speed and specificationflexibility into service design in the long term

b. Use of level design in the long term

c. Employment of part time and floating staff

d. Use of price and promotion strategies to smooth demand

4- Resource utilisation (with a focus on resource)

a. Utilisation of facilities, equipment and staff

5- $\quad$ Innovation ( with a focus on growth)

a. Measurement of the success of the innovation process and the innovation itself

6- Quality of service (with a focus on customer services)

a. Relationship between customer and organisation

b. Setting of clear customer expectations

c. Measurement of customer satisfaction 


\section{SCOR Model}

SCOR model is a reference tool to benchmark distinct supply chains across multiple industries. To achieve this, SCOR suggests a standardization of the processes and activities of a supply chain(mainly manufacturing supply chain) into five processes i.e. plan, source, make, deliver and return. "Plan" processes are the ones that balance aggregate demand and supply to develop a course of action which best meets sourcing, production and delivery. "Source" processes are related to procuring goods to meet demand. "Make" processes transform products to a finished state. "Deliver" processes provide finished goods to meet demand and "Return" processes are the ones that return products from the downstream to the upstream stages of the supply chain.

Each of the higher level process is sub-divided into three further levels that theoreticallyexplain the strategic, tactical and operational activities that exist to integrate the supply chain operations. The processes of anorganization's suppliers and customers are also considered in SCOR Model and integrated, thus providing an overall supply chain outlook. After mapping with SCOR terminology, the standardized processes can be analysed with the help of specific KPIs that still lack conprehensivenss with regard to their application in the service industries.

\begin{tabular}{ll} 
Attribute & Level-1 Metric \\
\hline Reliability & Perfect Order Fulfillment \\
\hline Responsiveness & Order Fulfillment Cycle Time \\
\hline Agility & Upside Flexibility \\
\cline { 2 - 2 } & Upside Adaptability \\
\hline Downside Adaptability \\
\hline Cost & Overall Value-at-Risk \\
\hline Asset Management Efficiency & Total Cost to Serve \\
\hline & Cash-to-Cash Cycle Time \\
\cline { 2 - 2 } & Return on Fixed Assets \\
\hline & Return on Working Capital \\
\hline
\end{tabular}

Fig. 1 SCOR performance attributes and associated level 1 metrices. (Version 11.0)Source: www.supply-chain.org

SCOR MODEL, (abbreviated as: Supply Chain Operational Reference MODEL) has four major components that act as reference points to help companies, when designing and implementing supply chain integration. These components are (SCC, 2008):

- Performance Metrics (Key Performance Indicators): Standard metrics to measure process performance by identifying the value specifics of how good a company is progressing

- Processes: Standard descriptions of

a) management processes and

b) a framework of process relationships

- Practices: Management practices that produce best-in-class performance

- People: Training and skills requirements aligned with processes, best practices, and metrics. 
The lack of adapted performance metrics and best practices for services supply chains make SCOR model an inadequate model for the management of service supply chains (Giannakis, 2011). The current loaded range of performance metrics however may guide us to the development of new performance measurement framewoks forservice supply chains.

\section{Balanced SCORECARD}

It was Kaplan and Norton (1992, 1993, 1996),whoformulated the concept of Balanced ScoreCard (BSC), that is principally a multi-dimensional performance measurement framework. The balanced scorecard is unique in a sense that it incorporates the non-financial in addition to the financial perspective for measuring orgaznizational performance and has four different areas including financial, customer, internalbusiness processes as well as learning and growth. Mainly this scorecard not only covers the strategic dimensions of the organizations but also operational dimensions thereof and is presented in Figure 2.

Based on their further research on intangible assets, (Kaplan and Norton, 2004) have graded intangible assets under three broad categories, namely, human capital (consisting of employees' skills, talent and knowledge), information capital (that includes databases, information systems, networks and technology infrastructure) and organization capital (encompassing culture, leadership, employee alignment, teamwork and knowledge management).

With the strength of the model acknowledged it has to be noted that, the balanced scorecard approach has not dealt with the requirements of all thestakeholders. The soft issues related to employees have not been considered, despite the fact that theemployees' skills and knowledge,as an intellectual asset, have been described as part of the learning and growth perspective. This perspective in the opinion of the authors deserves a a separate treatment given that they are so significant in the implementation of the management strategies.

One other factor that is generally overlooked in balanced scorecard approach is theconscientiousness of the organisation for the society in which it works and relates to the socialand stakeholders perspective. We know that in reality organisations do not function in isolated spacesbut are liable to the society as a whole.

\begin{tabular}{|c|c|c|c|}
\hline & Perspectives & Typical Objectives & Typical Measures \\
\hline & Financlal & $\begin{array}{l}\text { - Become industry cost leader } \\
\text { - Maximize use of existing assets }\end{array}$ & $\begin{array}{l}\text { - Cost per unit (vs. competitors) } \\
\text { - Annual reduction in cost per unit } \\
\text { - Sales/asset ratio } \\
\text { - Free cash flow }\end{array}$ \\
\hline & Customer & $\begin{array}{l}\text { - Lower customer's cost } \\
\text { - Deliver zero-defect products } \\
\text { - Provide on-time delivery }\end{array}$ & $\begin{array}{l}\text { - Customer's cost of ownership } \\
\text { - Defect rate } \\
\text { - Number of warranty claims } \\
\text { - Percentage of on-time deliveries }\end{array}$ \\
\hline & Develop supplier relationships & $\begin{array}{l}\text { - Lower total cost of ownership } \\
\text { - Achieve just-in-time capability } \\
\text { - Develop high-quality suppliers } \\
\text { - Achieve supplier partnership }\end{array}$ & $\begin{array}{l}\text { - Activity-based cost of acquisition } \\
\text { - Percentage of orders direct to production } \\
\text { - Percentage of late orders } \\
\text { - Percentage of suppliers qualified to bypass inspection } \\
\text { - Percentage of suppliers serving customer directly }\end{array}$ \\
\hline & Produce products and services & $\begin{array}{l}\text { - Lower cost of producing } \\
\text { - Improve process responsiveness } \\
\text { - Improve fixed-asset utilization } \\
\text { - Improve working-capital efficiency }\end{array}$ & $\begin{array}{l}\text { - Total cost of quality } \\
\text { - Number of processes with substantial improvement } \\
\text { - Cycle time } \\
\text { - Process efficiency } \\
\text { - Capacity utilization } \\
\text { - Inventory turnover }\end{array}$ \\
\hline
\end{tabular}


https://ir.iba.edu.pk/businessreview/vol10/iss2/9

DOI: https://doi.org/10.54784/1990-6587.1358

Business Review - Volume 10 Number 2

\begin{tabular}{|c|c|c|c|}
\hline \multirow{3}{*}{ 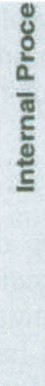 } & $\begin{array}{l}\text { Distribute products and } \\
\text { services to customers }\end{array}$ & $\begin{array}{l}\text { - Deliver responsively } \\
\text { - Lower cost to serve } \\
\text { - Enhance quality }\end{array}$ & $\begin{array}{l}\text { - Lead times (order to delivery) } \\
\text { - Percentage of on-lime deliveries } \\
\text { - Activity-based cost of storage and delivery } \\
\text { - Customer complaints }\end{array}$ \\
\hline & $\begin{array}{l}\text { Provide postsales } \\
\text { (ongoing) service }\end{array}$ & $\begin{array}{l}\text { - Respond to customer feedback } \\
\text { - Enhance postsales value }\end{array}$ & $\begin{array}{l}\text { - Time to resolve complaints } \\
\text { - Percentage of queries satisfied on first call } \\
\text { - Revenue/margin from postsales service }\end{array}$ \\
\hline & Manage risk & $\begin{array}{l}\text { - Manage financial risk } \\
\text { - Manage operating risk } \\
\text { - Manage technological risk }\end{array}$ & $\begin{array}{l}\text { - Bad debt percentage } \\
\text { - Losses from interest rates, currencies } \\
\text { - Inventory obsolescence } \\
\text { - Order bacilog } \\
\text { - Process technology ranking (vs, competition) }\end{array}$ \\
\hline$\sum_{0}^{5}$ & Human capital & $\begin{array}{l}\text { - Develop quality/process } \\
\text { improvement skills }\end{array}$ & $\begin{array}{l}\text { - Percentage of employees trained in } \\
\text { quality management } \\
\text { - Number of Six Sigma "black belis" }\end{array}$ \\
\hline$\infty$ & Information capital & $\begin{array}{l}\text { Provide technology that facilitates } \\
\text { process improvement }\end{array}$ & $\begin{array}{l}\text { - Percentage of employees receiving immediate feedback } \\
\text { - Percentage of customers who can track orders }\end{array}$ \\
\hline$\frac{5}{\frac{5}{2}}$ & Organizational capltal & $\begin{array}{l}\text { - Create a culture lor } \\
\text { continuous improvement }\end{array}$ & $\begin{array}{l}\text { - Performance improvement from employee suggestions } \\
\text { - Percentage of lideas shared across organization }\end{array}$ \\
\hline
\end{tabular}

Figure No. 2: Balanced scorecard templat

\section{Holistic SCORECARD}

The holistic scorecard approach presented by Sureshchandar and Rainer Leisten in (2005) and in an opinion can be considered as an extension of the balanced scorecard approach. In their method, 2-3 dimensions have been added to the balanced scorecard in order to make it more holistic and balanced in spirit.

This holistic scorecard not only describes the financial perspective, customer's perspective but also deals with business process, employee, intellectual capital and social perspectives, thus covering for the apparent shortcoming in the scorecard mentioned previously. Further, the authors in their discussion on KPIs observe that these vary from industry to industry and managers must adopt them according to the needs and requirements of the industry or organization. Even with these additional considerations, this scorecard model does not deal with the service industry in particular; although a case of IT industry has been written by these authors in order to validate the model for service industry. Figure 3 shows the schematic detail of Holistic Scorecard.

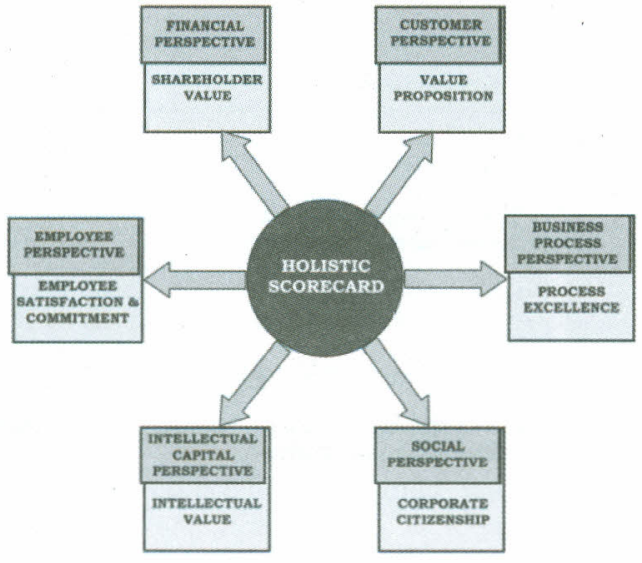

Figure No. 3: Holistic scorecard 
In the above section, we described some of the known models and have also highlighted the fact that these have generally dealt with manufacturing industries and with a very minute focus on the service industry.

\section{Methodology}

As stated earlier, the objective of the paper is to propose a model of KPIs for measuring performance in an integrated supply chain for the service industry. The following section will detail the process of systematic review of literature and the form adopted to develop a comprehensive integrated framework for measuring performance in the service industry.

To start with, 57 articles and research papers from the literature of supply chain performance measurement were drawn. The research papers and articles were selected using keywords of "supply chain", "performance measurement", "service", "models", "framework" as well as using Boullean operators withinand by rearranging the sequences. The journals that are mostly related to the field of supply chain management, operations management, logistics management, production and operations management, strategice management, supply management and distribution management were chosen from multiple research repositories i.e. Emerald, Ebsco host, Science Direct and Wiley. Articles available in journals related to other management fields were ignored.Table I shows the summary of the list of KPIs that have been taken from literature from 1995 to 2015 related to the supply chain performance measurement field. A total of 34 authors from 23 articlesand research papers were selected whose contribution to the field of supply chain performance measurement is proven.Table I further segregates the KPIs on the basis of its application to the manufacturing industry or both the manufacturing and services industries. An effort has also been made to further categorize the KPIs on the basis of their supply chain position i.e. whether the KPI is mostly used at the supplier, company, or the customer level

Table 1

\begin{tabular}{|c|c|c|c|}
\hline References & $\begin{array}{c}\text { Performance } \\
\text { Indicators }\end{array}$ & $\begin{array}{c}\text { Categorization based on } \\
\text { Application }\end{array}$ & $\begin{array}{l}\text { Categorization based on } \\
\text { position in the supply chain }\end{array}$ \\
\hline Stewart, (1995) & 11 KPIs proposed & $\begin{array}{l}6 \text { Mnfg \& } 5 \text { (Mnfg + } \\
\text { Services) }\end{array}$ & 4 co., and 7 (co. + supp.) \\
\hline $\begin{array}{l}\text { Lockamy and Spencer, } \\
\text { (1998) }\end{array}$ & 11 KPIs proposed & $\begin{array}{l}9 \text { Mnfg \& } 2 \text { (Mnfg + } \\
\text { Services) }\end{array}$ & 7 co. +3 supp. +1 cust. \\
\hline Beamon, (1998) & 19 KPIs proposed & $\begin{array}{l}13 \text { Mnfg \& } 6 \text { (Mnfg + } \\
\text { Services) }\end{array}$ & $\begin{array}{l}13 \text { co. }+4(\text { co. }+ \text { supp. })+2 \\
\text { cust. }\end{array}$ \\
\hline Jouenne, (2000) & 10 KPIs proposed & $\begin{array}{l}5 \text { Mnfg \& } 5 \text { (Mnfg + } \\
\text { Services) }\end{array}$ & 8 co. +2 cust. \\
\hline Gunasekaran et al., (2001) & 23 KPIs proposed & $\begin{array}{l}3 \text { Mnfg \& } 20 \text { (Mnfg + } \\
\text { Services) }\end{array}$ & $\begin{array}{l}10 \text { co. }+9 \text { (co. }+ \text { supp. })+3 \\
\text { cust }+1 \text { supp. }\end{array}$ \\
\hline De Toni and Tonchia, (2001) & $31 \mathrm{KPIs}$ proposed & $\begin{array}{l}18 \text { Mnfg \& } 13 \text { (Mnfg + } \\
\text { Services) }\end{array}$ & 26 co. +1 cust. +4 supp. \\
\hline Milgate, (2001) & $11 \mathrm{KPIs}$ proposed & $\begin{array}{l}5 \text { Mnfg \& } 6 \text { (Mnfg + } \\
\text { Services) }\end{array}$ & 7 co. +4 supp. \\
\hline
\end{tabular}


https://ir.iba.edu.pk/businessreview/vol10/iss2/9

DOI: https://doi.org/10.54784/1990-6587.1358

Business Review - Volume 10 Number 2

July - December 2015

\begin{tabular}{|c|c|c|c|}
\hline GCI, (2001) & 5 KPIs proposed & $\begin{array}{l}2 \text { Mnfg \& } 3 \text { (Mnfg + } \\
\text { Services) }\end{array}$ & $\begin{array}{l}3 \text { co. }+1 \text { (co. }+ \text { supp. })+1 \\
\text { supp. }\end{array}$ \\
\hline Dutta, (2002) & $\begin{array}{l}4 \text { KPIs proposed } \\
1 \text { KPIs proposed }\end{array}$ & $\begin{array}{l}1 \text { Mnfg \& } 3 \text { (Mnfg + } \\
\text { Services) } \\
1 \text { (Mnfg + Services) }\end{array}$ & 1 (co. + supp. $)$ \\
\hline Farris and Hutchison, (2002) & & & \\
\hline Sengun Yeniyurt, (2003) & 24 KPIs proposed & $\begin{array}{l}6 \text { Mnfg \& } 18 \text { (Mnfg + } \\
\text { Services) }\end{array}$ & 20 co. +4 cust. \\
\hline Carlo Rafele, (2004) & $29 \mathrm{KPIs}$ proposed & $\begin{array}{l}13 \text { Mnfg \& } 16 \text { (Mnfg + } \\
\text { Services) }\end{array}$ & $29 \mathrm{co}$ \\
\hline $\begin{array}{l}\text { Huan et al., (2004) (SCOR } \\
\text { model) }\end{array}$ & $12 \mathrm{KPIs}$ proposed & $\begin{array}{l}8 \mathrm{Mnfg} \& 4 \text { (Mnfg + } \\
\text { Services) }\end{array}$ & 7 co. +5 (co. + supp. $)$ \\
\hline $\begin{array}{l}\text { Simatupang and Sridharan, } \\
(2004)\end{array}$ & $15 \mathrm{KPIs}$ proposed & $\begin{array}{l}6 \text { Mnfg \& } 9 \text { (Mnfg + } \\
\text { Services) }\end{array}$ & $\begin{array}{l}13 \text { co. }+1(\text { co. }+ \text { supp. })+1 \\
\text { cust. }\end{array}$ \\
\hline Webster et al., (2004) & 6 KPIs proposed & 6 (Mnfg + Services) & $6 \mathrm{co}$ \\
\hline $\begin{array}{l}\text { Dft, } 2006 \text { b; Dft, 2004, Dft, } \\
\text { 2005; Dft, 2006c; Dft, } 2006 \mathrm{a}\end{array}$ & $39 \mathrm{KPIs}$ proposed & $\begin{array}{l}28 \text { Mnfg \& } 11 \text { (Mnfg + } \\
\text { Services) }\end{array}$ & 37 co. +2 cust. \\
\hline $\mathrm{ABB},(2005)$ & 9 KPIs proposed & $\begin{array}{l}4 \text { Mnfg \& } 5 \text { (Mnfg + } \\
\text { Services) }\end{array}$ & 8 co. +1 supp. \\
\hline Frameworx, (2005) & 5 KPIs proposed & $\begin{array}{l}2 \text { Mnfg \& } 3 \text { (Mnfg + } \\
\text { Services) }\end{array}$ & $5 \mathrm{co}$ \\
\hline Sigurd, (2005) & 2 KPIs proposed & $2 \mathrm{Mnfg}$ & 2 co. \\
\hline Bukk and Sigurd, (2005) & 8 KPIs proposed & $\begin{array}{l}4 \mathrm{Mnfg} \& 4(\mathrm{Mnfg}+ \\
\text { Services) }\end{array}$ & 8 co. \\
\hline & & $\begin{array}{l}3 \text { Mnfg \& } 1 \text { (Mnfg + } \\
\text { Services) }\end{array}$ & $4 \mathrm{co}$ \\
\hline Mumby, (2006) & 4 KPIs proposed & & \\
\hline $\begin{array}{l}\text { Blinge and Swensson, } \\
(2006)\end{array}$ & $5 \mathrm{KPIs}$ proposed & $\begin{array}{l}3 \text { Mnfg \& } 2 \text { (Mnfg + } \\
\text { Services) }\end{array}$ & $5 \mathrm{co}$ \\
\hline $\begin{array}{l}\text { Sxelerski, 2007; kuchnia and } \\
\text { Damogala, (2007) }\end{array}$ & $8 \mathrm{KPIs}$ proposed & $\begin{array}{l}3 \mathrm{Mnfg} \& 5 \text { (Mnfg + } \\
\text { Services) }\end{array}$ & $8 \mathrm{co}$ \\
\hline
\end{tabular}

$*(\mathrm{Mnfg} .=$ Manufacturing, $\mathrm{Co} .=$ Company. Cust. $=$ Customer, Supp. $=$ Supplier $)$ 


\section{Analysis and comments}

Following the research methodology, various gaps related to the field of supply chain performance measurement in services industry were revealed starting with the fact that the performance metrics for supply chain integration is currently an under researched topic. This observation is supported by Lambert \& Pohlen (2001) who points to the lack of empirical evidences of performance metrics and operation control at the general supply chain level. Although SCOR model has also suggested an approach for performance evaluation of supply chain integration to be followed at various levels (as defined in SCC (2008), where there are 3 levels of integration - supply chain, cross functional, and functional levels), it requires some very complicated tasks to follow, (Shepherd \& Guenter, 2006). For example, level 1 defines key supply chain metrics such as perfect order fulfilment, order fulfilment cycle time, cost of goods sold, total supply chain cost, supply chain adaptability, supply chain flexibility, cash to cash cycle time, return on supply chain fixed assets and working capital show the overall aggregate performances of companies. These metrics are connected further to level 2 and onwards. SCOR suggests the trading partners to adapt these performance metrics in each level of the supply chain integration in order to ensure the whole supply chain operations is being controlled in an integrated manner. However, the level 1 metrics suggested by SCOR are not actually measurable as most of them have been proposed at the conceptual level and not quantified. Moreover, adapting the SCOR metrics needs major surgery of business processes within the trading partners but there is no suggestion how it could be achieved in the SCOR framework. This weakness has been recently noted by Wang, et al (2010) who suggestedthat the investigation of easier approaches than provided by SCOR framework is becoming necessary.

Previous literature has mainly focused on manufacturing industries when providing the empirics of supply chain integration, particularly the study of performance metrics (e.g., Chow, Heaver, \& Henriksson, 1994; Esper, Defee, \& Mentzer, 2010; Andersen, Henriksen, \& Aarseth, 2006; Carlucci, 2010; Chae, 2009). One of the few examples adopting other sample industries is Hong et el (2010) who investigate the supply chain integration and the practices for manufacturers as well the distributors and other services providers. In their study, performance metrics are explored and discussed as the benchmarking tool for various products and services in the supply chain. Likewise, Kumar \& Markeset, (2007) conducted a study with the sevice sector of oil and gas industry. Given the above, it can be proposed that there is visible gap in proposing cross-functional metrics for supply chain integration in the service industry, where the concept of intangible comes into play. As stated earlier, the customers in service industry may also be the suppliers that forms a bi-directional supply chain which could be very difficult to evaluate (Sampson, 2000).

One of the researcher, Ellram et al. (2004) has tried to propose a service SCM framework, which estimates the usefulnessof existing SCM models and have adaptedseven processes of the global supply chain forum framework (Cooper et al., 1997) for application to a service supply chain. These are demand management, customer relationship management, supplier relationship management, service delivery management,cash flow, information flow, capacity and skills management. They basically view capacity management as a key to knowing theservice, by considering the process of providing a service as the transmitting of capacity for the purposes of providing value to the customer.

\section{Roadmap for the development of Operational Framework}

According to Melynk et al. (2004), metrics and measures provide essential links between strategy, execution and ultimate value creation. There are several factors that have contributed to the requirement for measures and metricsto manage a supply chain (Chan and Qi, 2003; Lambert and Pohlen, 2001) which need to go beyond internal measures and metrics and look at the supply chain asa whole. It should also link the supply chain performance and 
corporate objectives while expanding the "line of sight" within the supply chain. Further benefits should be alloacated and burdens shifted resulting from functional shifts within the supply chain. Additionally, it should encourage co-operative behavior within the supply chain, enhance motivation, improve communication, and diagnose problems within the supply chain; and lastly it should try to improve the performance of the supply chain and thus providing competitive advantage. These factors indicate that one must look at all the dimensions of the application in order to measure the performance. In doing so, one must look not only at the tangible asset side but intangible also including the behavioural and cultural aspects. The KPIs mentioned in the annexure I are the ones that are mostly used by the manufacturing industry managers and have less application in the service sector. Some of these KPIs are also applicable to services industries but the application and the nature of the formula will have to be fine tuned,which is a cumbersome process. In order to do it effectively, one has to carefully observe the rationale of the KPI and its formula and also have to keep in mind the point in the industry where it is going to be applicable. During the application of the KPI, one needs to remember that the service industry environment is more dynamic compared to manufacturing environment therefore a margin to continuously revise the formula should also be kept in mind.

A list of KPIs is given in the Table II that are recommended for manufacturing and services environment both. The total no. of KPIs come out to be 117 . There is still a huge gap left even if we use all KPIs for service industries. The gap is due to various dimensions of service industries that are not yet fully explored and measured. These 21 dimensions are related to time, cost, quality and further connected to safety, innovation, growth, organizational culture, document handling, flexibility, reliability, trust, communication, adaptability, relationship management, partnership, social capital, intellectual capital, human capital measurement, uncertainty evaluation, return process evaluation and asset utilization. The road map to develop the operational level framework based on the information retrieved so far would look like this:
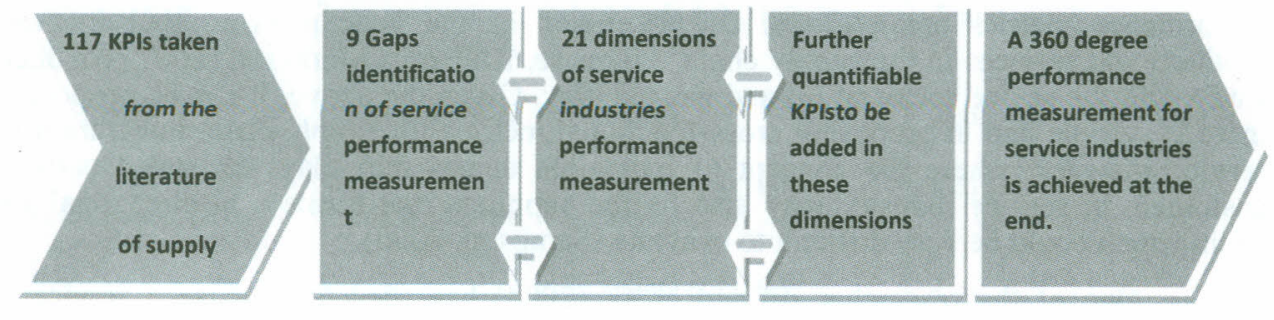

Figure No:4: Road map to develop operational Framework for Service Supply Chain Performance Measurement

Table II

KPIs those are applicable to both manufacturing and service industries

\begin{tabular}{|l|l|}
\hline$\%$ of late deliveries & Forecast accuracy \\
Accident impact & Forecast reliability \\
Accident severity rate & Fuel costs \\
Administration and management cost & Growth \\
\hline
\end{tabular}


https://ir.iba.edu.pk/businessreview/vol10/iss2/9

DOI: https://doi.org/10.54784/1990-6587.1358

\begin{tabular}{|c|c|}
\hline Average lateness & Harmfulness \\
\hline Back orders & Health issues \\
\hline Breadth of supply base & impact on strategy \\
\hline Buyer-vendor cost saving initiatives & Improved planning process \\
\hline Capacity utilization & Inbound quality \\
\hline Cash to cash cycle time & Indirect labor productivity \\
\hline Claims management & information availability \\
\hline Clean data & Infrastructure cost \\
\hline Communication & Labor cost \\
\hline Costs associated with assets & less stressful work for planners \\
\hline Customer complaints statistics & $\begin{array}{l}\text { Level and degree of information } \\
\text { sharing }\end{array}$ \\
\hline Customer perception of service & Lost sales \\
\hline Customer query time & Margin \\
\hline Customer retention & Market orientation \\
\hline Customer satisfaction & Market share \\
\hline Customer services levels & No. of back orders \\
\hline Data security & No. of client contacts \\
\hline Days of sales outstanding & No. of faultless notes invoiced \\
\hline Delivery lead time & No. of orders delivered on time \\
\hline Delivery reliability & No. of process innovations \\
\hline Delivery to commit date & No. of promotions \\
\hline Delivery to request data & No. of urgent orders \\
\hline Distribution of internal competencies & On time delivery \\
\hline Document management & Operating costs \\
\hline $\begin{array}{l}\text { Early warnings of anticipated supply } \\
\text { problems }\end{array}$ & Operational flexibility \\
\hline Ease of ordering & Order advancement state \\
\hline Effectiveness of scheduling techniques & Order fulfillment lead time \\
\hline Efficiency & Order management cost \\
\hline Employee satisfaction index & People costs \\
\hline Employee training hours & Perceived quality \\
\hline Employee turnover rate & Personal efficiency \\
\hline EVA & Personnel cost \\
\hline
\end{tabular}


Extent of mutual assistance in problem solving efforts

Extent of mutual cooperation leading to improved quality

Extent of outsourcing

Fixed capital productivity

Flexibility of delivery systems to meet customer needs

Quality system cost

Range of products and services

Reduction of staff

Regularity

Repeat sales level

Response against changes in the customer order

Responsiveness

Return on investment

Customer returns / rejections

Revenue

Risk index

ROA

ROCE

Sales

Sales per employee

Supplier lead time

Supplier on time delivery

Supplier outgoing quality level

Supplier reliability
Post transaction measures of customer service

Potential access to wider customer base

Profit per employee

Punctuality

Supply chain responsiveness

the entity and stage at which supplier is involved

Time keeping

Time to market

Total cash flow time

Total costs

Total order cycle time

Total savings

Total Supply Chain Cost

Value added employee productivity

Value added productivity

Vendor quality rating

Waiting time percentage

Web site completeness

Working capital productivity

Working environment index

Working time

\section{Conclusion}

The research topic is contemporary. The prospective research output would provide relevant managerial implications and will potentially contribute to the existing body of knowledge as follows:

This analysis will enable the identification of the problems that surround outcome assessment within and across single supply chains and extend existing knowledge in the end- 
to-end supply chain performance measurement in the service industry. Further this analysis should provide some vital insights as to how service organizations can improve their performance evaluation systems to become more effective in supply chains. A set of supply chain enablers is also suggested across various business entities, portraying the performance of the supply chain suitable for needs of companies along with filling gaps that become identifiable.

This study aims to not only identify the gaps present in the service supply chain performance measuremnet but tries to fill the knowledge gap to suggest performance metrics in facilitating the supply chain integration in the service industry. These gaps are summarized as follows:

- KPIs not provided at the SCM level

- KPIs are not measurable

- Lack of empirical evidences for KPIs

- SCOR KPIs require very complicated tasks to follow

- SCOR framework for services industry requires major business process reengineering

- $\quad$ KPIs are focused on manufacturing

- BSC not useful for IT industry

- BSC not dealt with the requirements of all stakeholders

- $\quad$ BSC doesnt deal with soft issue

- $\quad$ BSC ignores the social perspective

Through the exploring of 21 dimensions of service industries, further KPIs could be proposed and finally this output will be reviewed on continuous basis so as to ensure

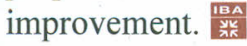

\section{References}

Abu Bakar, A. H., Hakim, I. L., Chong, S. C., \& Lin, B. (2010). "Measuring supply chain performance among public hospital laboratories". International journal of productivity and performance management, Vol. 59 No. 1, pp. 75-97.

Andersen, B., Henriksen, B., \& Aarseth, W. (2006). "Holistic performance management: an integrated framework". International journal of productivity and performance management, Vol. 55 No. 1, pp. 61-78.

Asrofah, T., Zailani, S., \& Fernando, Y. (2010). "Best practices for the effectiveness of benchmarking in the indonesian manufacturing companies". Benchmarking: an international journal, Vol. 17 No. 1, pp. 115-143.

F. Bustinza, O., C. Parry, G. and Vendrell-Herrero, F. (2013), "Supply and demand chain management: The effect of adding services to product offerings", Supply Chain Management: an international journal, Vol. 18 No. 6, pp. 618-629

Carlucci, D. (2010). "Evaluating and selecting key performance indicators: an ANP-based model". Measuring business excellence, Vol. 14 No. 2, pp. 66-76.

Chae, B. K. (2009). "Developing key performance indicators for supply chain: an industry perspective". Supply Chain Management: an international journal, Vol. 14 No. 6, pp. 422428 .

Chahal, H. and Kaur, J. (2014), "Development of marketing capabilities scale in banking sector", Measuring Business Excellence, Vol. 18 No. 4, pp. 65-85. 
Chan, F. and Qi, H.J. (2003), "Feasibility of performance measurement system for supply chain: a process-based approach and measures", Integrated Manufacturing Systems, Vol. 14 No. 3, pp. 179-190

Chan, H., Wang, W. Y., Luong, L. H., \& Chan, F. T. (2009). "Flexibility and adaptability in supply chains: a lesson learnt from a practitioner". Supply chain management: an international journal, Vol. 14 No. 6, pp. 407-410.

Chia, A., Goh, M., \& Hum, S.-H. (2009). "Performance measurement in supply chain entities: balanced scorecard perspective". Benchmarking: an international journal, Vol. 16 No. 5, pp. 605-620.

Chow, G., Heaver, T. D., \& Henriksson, L. E. (1994). "Logistics performance: definition and measurement". International journal of physical distribution and logistics management, Vol. 24 No. 1, pp. 17-28.

Cooper, M.C., Lambert, D.M. \& Pagh, D. (1997), "Supply chain management: more than a new name for logistics?", The International Journal of Logistics Management, Vol. 8 No. 1, pp. 1-14.

Coyle, J. J. (1990). "Preparing logistics systems for 21st century". Proceedings: Council of Logistics Management, Annual Conference. 2, pp. 1-10. IL: Oak Brook.

Darkow, I.-L., Foerster, B. and von der Gracht, H. A. (2015), "Sustainability in food service supply chains: future expectations from European industry experts toward the environmental perspective", Supply Chain Management: an international journal, Vol. 20 No. 2, pp. 163178

Denzin, N.K. \& Lincoln, Y.S. (1984), Handbook of Qualitative Research, Newbury Park: Sage Publications

De Toni, A. F., Fornasier, A., Montagner, M., \& Nonino, F. (2007). "A performance measurement system for facility management. The case study of a medical service authority". International journal of productivity and performance management, Vol. 56 No. 5-6, pp. 417435.

Dey, P. K., Hariharan, S., \& Clegg, B. T. (2006). "Measuring the operational performance of intensive care units using the analytic hierarchy process approach". International journal of operations and production management, Vol. 26 No. 8, pp. 849-865.

Ellram, L., Tate, W. and Billington, C. (2007), "Services supply management: the next frontier for improvedorganisational performance", California Management Review, Vol. 49No. 4, pp. 44-66.

Ellram, L., Tate, W. \& Billington, C. (2004), "Understanding and managing the services supply chain", Journal of Supply Chain Management, Vol. 40 No. 4, pp. 17-32.

Esper, T. L., Defee, C. C., \& Mentzer, J. T. (2010). "A framework of supply chain orientation". The international journal of logistics management, Vol. 21 No. 2, pp. 161-179.

Ethridge, E. D. (2004). Research Methodology in Applied Economics: Organizing, Planning, and Conducting Economic Research, Victoria: Blackwell Publishing Asia

Fawcett, S. E., \& Clinton, S. R. (1997). "Enhancing logistics to improve the competitiveness of manufacturing organizations, a triad perspective". Transportation Journal, Vol. 37 No. 1, pp. 18-28.

Fitzgerald, L., Johnston, R., Brignall, T., Silvestro, R. \& Voss, C. (1991), "Performance Measurement in Service Businesses", CIMA, London. 
Flynn, B. B., Huo, B. \& Zhao, X.( 2010). "The impact of supply chain integration on performance: A contingency and configuration approach". Journal of Operations Management, Vol. 28 No. 1, pp. 58-71.

Forslund, H., \& Jonsson, P. (2007). "Dyadic integration of the performance management process. A delivery service case study". International journal of physical distribution and logistics management, Vol. 37 No. 7, pp. 546-567.

Frohlich, M.T. \& Westbrook, R. (2001). "Arcs of integration: an international study of supply chain strategies". Journal of Operations Management, Vol. 19 No. 2, pp. 185-200.

Giannakis, M (2011). "Management of service supply chains with a service oriented reference model: the case of management consulting". Supply chain management: an international journal, Vol. 16 No. 5, pp. 346-361.

Hofmann, E., \& Locker, A. (2009). "Value-based performance measurement in supply chains: a case study from the packaging industry". Production planning and control, Vol. 20 No. 1, pp. 68-81.

Hong, P. C., Dobrzykowski, D. D., \& Vonderembse, M. A. (2010). "Integration of supply chain IT and lean practices for mass customization. Benchmarking of product and service focused manufacturers". Benchmarking: an international journal, Vol. 17 No. 4, pp. 561592.

Hyde, K. F. (2000). "Recognizing Deductive Processes in Qualitative Research", Qualitative Market Research: An International Journal, Vol. 3 No. 2, pp. 82-89

Jonker, J. \& Pennink, B. W. (2010). “The Essence of Research Methodology: A Concise Guide for Master and PhD Students in Management Science", New York: Springer, Heidelberg Dordrecht

Kaplan, R., \& Norton, D. (1992). "The balanced scorecard: Measures that drive performance". Harvard Business Review, Vol. 70 No. 1, pp. 71-99.

Kaplan, R., \& Norton, D. (1996). "Using the balanced scorecard as a strategic management system". Harvard Business Review, Vol. 74 No. 1, pp. 75-85.

Kaplan, R.S. and Norton, D.P. (1993), "Putting the balanced scorecard to work", Harvard Business Review, Vol. 71 No. 5,pp. 134-142.

Kaplan, R.S. and Norton, D.P. (1996), "The Balanced Scorecard - Translating Strategy into Action", Harvard Business School Press, Boston, MA.

Kaplan, R.S. and Norton, D.P. (2004), "Measuring the strategic readiness of intangible assets", Harvard Business Review, Vol. 82 No. 2, pp. 52-63.

Kumar, R., \& Markeset, T. (2007). "Development of performance-based service strategies for the oil and gas industry: a case study". Journal of business and industrial marketing, Vol. 22 No. 4 , pp. 272-280.

Lakshman, M., Sinha, L., Biswas, M., Charles, M. \& Arora, N. K. (2000). "Quantitative Vs Qualitative Research Methods", Indian Journal of Pediatrics, Vol. 67 No. 5, pp. 369-377

Lambert, D. M., \& Pohlen, T. L. (2001). "Supply Chain Metrics". The international journal of logistics management, Vol. 12 No. 1, pp. 1-19.

Mack, N., Woodsong, C., MacQueen, K. M. Guest, G. \& Namey, E. (2005). Qualitative Research Methods: A Data Collector's Filed Guide, Family Health International, Research Triangle Park, North Carolina, USA 
Maas, S., Herb, S. and Hartmann, E. (2014), "Supply chain services from a service-dominant perspective: a content analysis", International Journal of Physical Distribution \& Logistics Management, Vol. 44 No. 1/2, pp. 58-79

Melynk, S.A., Stewart, D.M. and Swink, M. (2004), "Metrics and performance measurement in operations management: dealing with the metrics maze", Journal of Operations Management, Vol. 22 No. 3, pp. 209-218.

Merriam, S. (1998). Qualitative research and case study: Applications in education. San Francisco: Jossey-Bass Publishers.

Patton, J. (1996). Analysis of thinking and research about qualitative methods. New Jersey: Lawrence Erlbaum.

Perry, C. \& Jensen, O. (2001). “Approaches to Combining Induction and Deduction in One Research Study", Paper Presented at the Australian and New Zealand Marketing Academy Conference (ANZMAC), 1-5 December, 2001, Albany, Auckland, availableat:http://smib.vuw.ac.nz:8081/WWW/ANZMAC2001/anzmac/AUTHORS/pdfs/Per ry1.pdf

Sampson, S. E. (2000). "Customer-supplier duality and bidirectional supply chains in service organizations". International journal of service industry management, Vol. 11 No. 4, pp. 348-364.

Sampson, S.E. and Spring, M. (2012), "Customer Roles in the Service Supply Chain and Opportunities for Innovation," Journal of Supply Chain Management, Vol. 48 No. 4, pp. 3050.

Sampson, S.E. and Spring, M. (2012), "Service Supply Chains: Introducing the special topic forum", Journal of Supply Chain Management, Vol. 48 No. 4, pp. 3-7

Sampson, S. E., (2012), “Visualizing Service Operations," Journal of Service Research, Vol. 15 No. 2, pp. 182-198.

Serve, M., Yen, D.C., Wang, J.C., \& Lin, B. (2002), "B2B-enhanced supply chain process: toward building virtual enterprises". Business Process Management Journal, Vol. 8No. 3, pp. 245-253.

Seth, N., Deshmukh, S., \& Vrat, P. (2006). "A framework for measurement of quality of service in supply chains". Supply Chain Management: An international journal, Vol. 11 No. 1, pp. 82-94.

Shepherd, C., \& Guenter, H. (2006). "Measuring supply chain performance: current research and future directions". International journal of productivity and performance management, Vol. 55 No. 3-4, pp. 242-258.

Sogunro, O. A. (2001). "Selecting a Quantitative or Qualitative Research Methodology: An Experience",Educational Research Quarterly, Vol. 26 No. 1, pp. 3-6.

Stevens, G.C. (1989). "Integrating the supply chain". International Journal of Physical Distribution \& Materials Management, Vol. 19 No. 8, pp. 3-8.

Stock, J. R., \& Boyer, S. L. (2009). "Developing a consensus definition of supply chain management: a qualitative study". International Journal of Physical Distribution and Logistics Management, Vol. 39 No. 8, pp. 690-711.

G.S. Sureshchandar and Rainer Leisten, (2005), "Holistic scorecard: strategic performance measurement and management in the software industry", Measuring Business Excellence, Vol. 9 No 2, pp. $12-29$. 
Supply Chain Council, (2008), Overview of SCOR Version, Vol. 10 No. 2, pp. 1-24.

Supply-Chain Council, Inc. "Supply-Chain Operations Reference Model: Overview of SCOR Version 11.0," www.supply-chain.org, accessed on February $3^{\text {rd }}, 2014$.

Thomas, D. R. (2003). A General Inductive Approach for Qualitative Data Analysis, Working Paper, School of Population Health, University of Auckland, New Zealand, August 2003

Voss, C.A. and Hsuan, J. (2009), "Service architecture and modularity", Decision Sciences, Vol. 40, pp. 541-69.

Wang, Q., Lai, F., \& Zhao, X. (2008). "The impact of information technology on the financial performance of third-party logistics firms in China". Supply chain management: an international journal, Vol. 13 No. 2, pp. 138-150.

Wang, Q., Voss, C., Zhao, X., wang, z. and Chan, H. K. (2015), "Modes of Service Innovation: A Typology", Industrial Management \& Data Systems, Vol. 115 No. 7

Wang, J., Yan, R. and Zhou, B. (2013), "A comparative study of US and international sustainability", International Journal of Applied Decision Sciences, Vol. 6 No. 1, pp. 15-34

Yin, R. (1984). Case study research: Design and methods (1st ed). Beverly Hills, CA: Sage Publishing.

Yin, R. (1994). Case study research: Design and methods (2nd ed). Thousand Oaks, CA: Sage Publishing.

Zimmermann, K., \& Seuring, S. (2009). "Two case studies on developing, implementing and evaluating a balanced scorecard in distribution channel dyads". International journal of logistics: research and applications, Vol. 12 No. 1, pp. 63-81.

Not failure, but low aim is crime. James Russell Lowell

David Olive \& Gita Piramal, The Quotable Tycoon: A treasury of business quotations, Page 83 